\title{
Different spaces: Staff development for Web 2.0
}

\author{
Gayani Samarawickrema \\ Deakin University \\ Robyn Benson and Charlotte Brack \\ Monash University
}

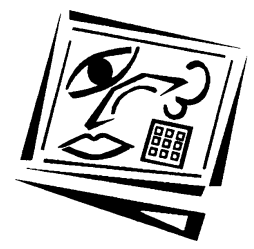

An Outstanding Paper Award recipient, ascilite Auckland 2009 Conference

\begin{abstract}
This paper reports on a collaborative staff development activity run across two Australian universities, for academic staff integrating Web 2.0 technologies into their teaching. It describes a three-week long virtual workshop on teaching with wikis, where participants in two groups developed a group project as students and then assessed the work as teachers. Participants were guided through a central Wikis in Higher Education wiki which provided the resources and communication supports. The experience suggested that teaching in a Web 2.0 space requires new thinking about pedagogy and that peer learning and the development of an online community are helpful for effective professional development. In closing, the paper reflects on the successes and limitations of this virtual workshop model.
\end{abstract}

\section{A different space}

Many teaching staff are exploring the opportunities of Web 2.0 technologies, including wikis, blogs, social bookmarking and social networking services, for their learning and teaching value (Choy \& Ng, 2007; Elgort, Smith \& Toland, 2008). If successful learning is to occur in these new learning spaces, teachers need to rethink their approaches and realign their teaching with the pedagogical possibilities the technologies offer. The social aspects of Web 2.0 technologies provide obvious potential for collaborative group learning. They allow all users to write, edit and co-construct knowledge, offering an online space where students can have greater responsibility for and control of their learning. While teachers may choose to use Web 2.0 software to help students to meet specific learning objectives, they need to allow the structure of environments to emerge from group interaction. In this way control of the environment lies with the group and is in the hands of the learners who make up the group and are influenced by the group. This gives teachers insight into a group's dynamics, strengths, weaknesses and how contributions to the group output develop (Dron, 2007a; Dron, 2007b). These possibilities of Web 2.0 environments, which enable students to work with evolving content online through reading, writing, editing, and communicating require teachers to reshape their approaches and move beyond restrictive, teachercontrolled environments to spaces that allow and encourage learner control.

In the context of Web 2.0 technologies, Moore (2007) invites teachers to consider a role change: using projects as a learning strategy; respecting the nature and nurture of self directed learning; managing dialogues between learners and between learners and teachers; and taking into account the changing concepts of learning structures and 
teaching systems. Pointing to Web 2.0's capacity to allow self organisation, which results in organic and emergent structures that offer bottom up control rather than top down design, Dron (2007b, p. 62) observes the value to learners of 'allowing the social construction of meaning and relatively effortless collaboration in new and interesting ways'. These collaborative and co-creative possibilities offer opportunities for sharing and group learning and require teachers to develop a pedagogy that optimises these advantages, so that learners benefit from virtual knowledge building which reflects 'the wisdom of crowds' (Surowiecki, 2004). This can be a challenging new skill for teachers, one that requires resources and support. Professional development skills based workshops on how to use the technology, show and tell sessions by successful technology adopters, and forums and seminars are helpful to prepare staff for online teaching, but are limited in allowing them to understand the student's experience in these new spaces. Situating staff development activities in authentic contexts and providing opportunities to share experiences, ideas and reflections with others are particularly valuable strategies (Wilson \& Stacey, 2004). They offer potential for taking staff to a deeper understanding of the technologies and how to use them for teaching. To explore this approach, we designed a professional development workshop to support staff in teaching with wikis and offered it at Deakin University and Monash University in Australia.

In designing the workshop, we drew on the concept of situated cognition where learning is seen as a process grounded in real world actions and knowledge is acquired situationally (Anderson, Reder, \& Simon, 1996). This was informed by a constructivist approach where learners engage in authentic activities (Honebein, Duffy \& Fishman, 1993). The online (virtual) environment we designed for the workshop allowed participants to experience the complexity and ambiguity of real world challenges, embedding learning in the social context within which it would be used (Brown, Collins \& Duguid, 1989). Thus, the development of a communal space reflected key concepts from social constructivism (Vygotsky, 1978) which included the importance of support through scaffolding. We also recognised the potential of collegial networks which support institutional goals (Camblin \& Steger, 2000) and the importance of learning occurring in a community, as a means of integrating technology into teaching (Judge \& O’Bannon, 2008).

\section{Procedure}

A crucial part of the design of the workshop was that participants would work in a wiki as students would, and then analyse the experience as teachers. Our workshop consisted of a primary workshop site called Wikis in Higher Education, which was a wiki that consisted of: a set of resources about the use of wikis in higher education; a workshop task to be completed by the two groups, each consisting of Deakin and Monash participants; guidelines on working in a wiki; and links to two workshop wikis that participants would develop as 'students'. Thirteen participants volunteered for the workshop (seven from Deakin and six from Monash), including one associate professor, one courseware developer and eleven lecturers. We divided them into two groups and allocated seven participants to Workshop Wiki 1 and six to Workshop Wiki 2. The relationships between the wikis are shown in Figure 1.

We started the workshop by emailing participants with instructions for logging into the Wikis in Higher Education site. We invited them to introduce themselves to other participants, identify their groups and locate their workshop wiki to respond to the task. We advised them that by completing the task they would engage in a wiki as a 
student and work collaboratively to create a body of work. Each of the workshop wikis was only accessible to its own group members. When this phase was complete we asked participants to review the work of the other group as teachers. The workshop task was designed to be similar to a group project students might undertake in a wiki, requiring an outcome which was assessable as a group product, but also allowing assessment of individual contributions. Two weeks were allocated to complete the task. The third week was allocated for a debrief when the two wikis were made 'read only' and opened for workshop participants to critique the output and individual and group participation of the other group. During this period participants were also asked to reflect on the experience of participating in a wiki and evaluate the workshop.

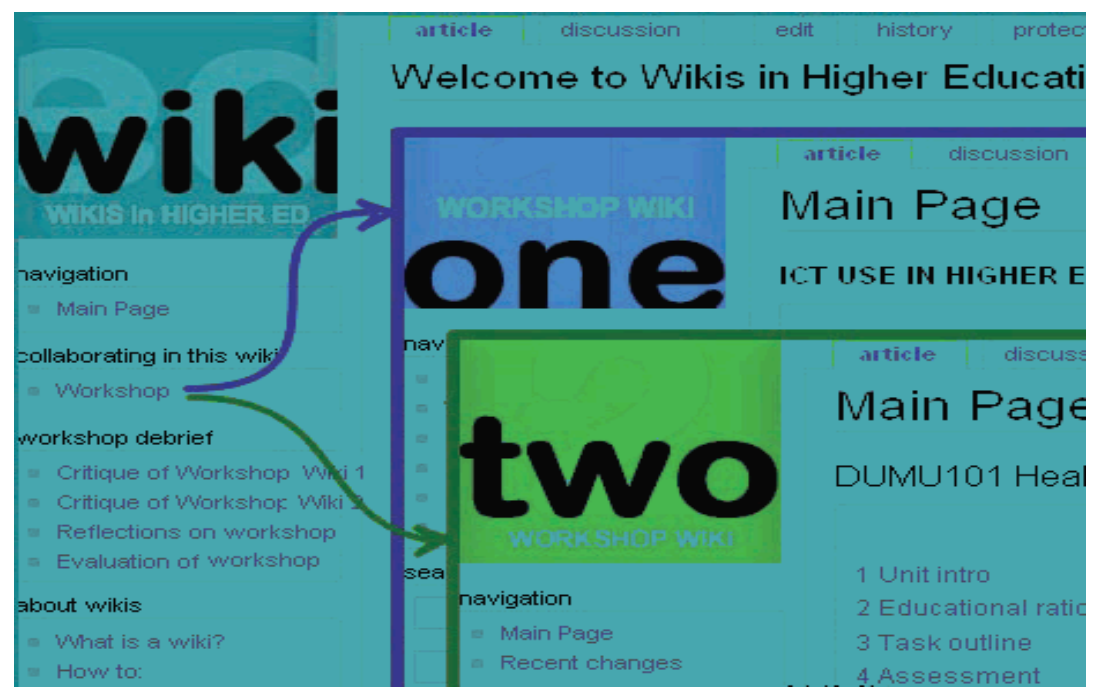

Figure 1: Wikis in Higher Education site and its connections to the two workshop wikis (Samarawickrema, Benson \& Brack, 2008, p. 88)

\section{Outcomes}

\section{Task progress}

Six of the 13 participants introduced themselves on the first day and by the second day 12 of them had accessed the Wikis in Higher Education site. By day 3, four participants had accessed Workshop Wiki 1 while two had accessed Workshop Wiki 2. On the fifth day two participants from Workshop Wiki 1 commenced the task but there was minimal progress in Workshop Wiki 2. At the end of the first week four participants had accessed each of the workshop wikis. As progress was slow, over the second week we added messages in both wikis to support participants and also some headings in Workshop Wiki 2 to model the use of space in a wiki. At the end of the second week, five participants had accessed Workshop Wiki 1 and six had accessed Workshop Wiki 2. Workshop Wiki 1 was in a more advanced state than Workshop Wiki 2. We have explained the daily progress made by participants elsewhere (Samarawickrema, Benson \& Brack, 2008). As facilitators, we acted as observers during task completion, but since the anticipated discussions did not take place on the Wikis in Higher Education site, we also sent group and individual emails of encouragement and support to participants. We took a more proactive role during the debrief. 


\section{Debrief}

This was conducted in three parts:

1. Critique: In critiquing each other's wikis, participants of Workshop Wiki 1 commented that Workshop Wiki 2 was poorly proof read, was confined to the main page, lacked focus on the task and called for better content organisation. Commenting on the group effort, participants of Workshop Wiki 2 were critiqued for spending too much time on the task context rather than the task itself. On the other hand, participants of Workshop Wiki 2 were impressed with the content in relation to clarity and navigation in Workshop Wiki 1. Their group effort was also commended.

2. Reflection: Eight participants contributed their reflections on their experience of participating in the workshop. They believed that the workshop helped them to contextualise how to use wikis and how to introduce them to students. Other reflections were about the need for more time for discussion, planning, familiarisation with wiki functions, group formation, and editing others' work.

3. Evaluation: Five participants contributed to the workshop evaluation. They believed that the experience of participation was the most useful aspect of the workshop. The lack of time for the task and for group formation and a sense of needing more guidance were other observations they made.

\section{Discussion}

The workshop highlighted the wide ranging wiki experience of participants. Two had previous wiki experience but most found the new space unfamiliar, requiring more orientation than that provided by the Wikis in Higher Education wiki. Despite considerable effort at facilitation via this central wiki, we found it more difficult to provide appropriate support in the online environment than in our experience of face to face orientation sessions. Analysis of the task progress indicated that participants had difficulty in the planning and group formation stages. They hesitated to take leadership, undertake specific roles or to edit peer work and instead sought consensus which slowed the process (especially in Workshop Wiki 2), while a few did not contribute at all. However, the evaluation comments indicated that the basic design of the workshop was appropriate, including the objectives, the idea of a collaborative task that reflected an assessable student project, and the debrief. A longer time frame for the workshop may have alleviated the difficulties described above and facilitated collaborative work, though we did not consider that a longer workshop would be realistic for busy academics. Some debrief comments suggested that the groups should have been provided with a leader, but this would have removed participant negotiation of roles and undermined the egalitarian nature of a wiki. Reflecting on their experience and drawing on the features of wikis, participants suggested a number of approaches for using wikis in teaching, indicating attempts at applying this experience to their own teaching needs and contexts.

Evaluation comments included requests for more professional development of this kind ('I enjoyed it so keep me in mind for more'; '... count me in for another one. I liked it'). There was also appreciation of the inter-university effort ('A worthwhile exercise especially because it involved a collaborative effort between 2 Melbourne Universities... I would also be happy to try again'). One participant requested 
permission to 'copy and paste' information from the Wikis in Higher Education into a site she was setting up for her students, confirming the usefulness of this information to her.

\section{Conclusion}

Staff development relating to Web 2.0 technologies must not only enthuse teachers about the pedagogical value of the environment, but also provide opportunities to make appropriate technological choices. Giving staff the opportunity to experience new learning spaces was advantageous for supporting informed design of collaborative learning experiences for their students. As one participant commented, experience in the virtual space helped to do this by 'contextualis[ing] how social software could be used for teaching'. The three week workshop gave participants experience with an authentic task in a virtual space, providing them with insights into the characteristics of wikis and their potential for teaching, and confirming the value of this virtual workshop model. Participants' evaluations and our own reflections on difficulties with orientation to the wiki environment suggested that a blended approach may expedite future workshops. Starting the workshop in a physical space would support group formation and clarification of the nature of the workshop, which would in turn orientate participants to collaborate in the virtual space, offering a blended learning experience. Such an adjustment in any future offerings of this workshop would be an improvement on the current model that would accommodate issues raised in the evaluation.

\section{References}

Anderson, J. R., Reder, L. M. \& Simon, H. A. (1996). Situated learning and education. Educational Researcher, 25(4), 5-11.

Brown, J. S., Collins, A. \& Duguid, P. (1989). Situated cognition and the culture of learning. Educational Researcher, 18(1), 32-42.

Camblin, L. D. Jr \& Steger, J. A. (2000). Rethinking faculty development. Higher Education, 39, 118.

Choy, S. \& Ng, K. (2007). Implementing wiki software for supplementing online learning. Australasian Journal of Educational Technology, 23(2), 209-226. http: / / www.ascilite.org.au/ajet/ajet23/choy.html

Dron, J. (2007a). Control and constraint in e-learning: Choosing when to choose. Hershey, PA: Idea Group Publishing.

Dron, J. (2007b). Designing the undesignable: Social software and control. Educational Technology $\mathcal{E}$ Society, 10(3), 60-71. http: / / www.ifets.info/journals/10_3/5.pdf

Elgort, I., Smith, A. G. \& Toland, J. (2008). Is a wiki an effective platform for group course work? Australasian Journal of Educational Technology, 24(2), 195-210. http: / / www.ascilite.org.au/ajet/ajet24/elgort.html

Honebein, P. C., Duffy, T. M. \& Fishman, B. J. (1993). Constructivism and the design of learning environments: Context and authentic activities for learning. In T. M. Duffy, J. Lowyck \& D. H. Jonassen (Eds.), Designing environments for constructivist learning (pp.87-108). Berlin: Springer-Verlag. 
Judge, S. \& O'Bannon, B. (2008). Faculty integration of technology in teacher preparation: Outcomes of a development model. Technology, Pedagogy and Education, 17(1), 17-28.

Moore, M.J. (2007) Foreword. In J. Dron (Ed.), Control and constraint in e-learning: Choosing when to choose (pp.ix-xii). Hershey, PA: Idea Group Publishing.

Samarawickrema, G., Benson, R. \& Brack, C. (2008). Teaching with wikis: Addressing the digital divide. In N. Whitton \& M. McPherson (Eds.), ALT-C 2008: Rethinking the digital divide (pp.8494). Leeds, UK: Association for Learning Technology. UK.

http: / / repository.alt.ac.uk/440/1/ ALT_C_2008_rp_samarawickremag_bensonr_brackc.pdf

Surowiecki, K. (2004). The wisdom of crowds. New York: Doubleday.

Vygotsky, L. (1978). Mind in society: The development of higher psychological processes. Cambridge, MA: Harvard University Press.

Wilson, G. \& Stacey, E. (2004). Online interaction impacts on learning: Teaching the teachers to teach online. Australasian Journal of Educational Technology, 20(1), 33-48. http: / / www.ascilite.org.au/ajet/ajet20/wilson.html

This article received an Outstanding Paper Award at ascilite Auckland 2009, gaining the additional recognition of publication in AJET (with minor corrections). The reference for the conference version is:

Samarawickrema, G., Benson R. \& Brack, C. (2009). Different spaces: Staff development for Web 2.0. In Same place, different spaces. Proceedings ascilite Auckland 2009. http:/ / www.ascilite.org.au/ conferences/auckland09/procs/ samarawickrema.pdf

Authors: Dr Gayani Samarawickrema is a Lecturer at the Institute of Teaching and Learning at Deakin University, Australia.

Email: Gayani.Samarawickrema@deakin.edu.au

Dr Robyn Benson is a Senior Lecturer in the Faculty of Medicine, Nursing and Health Sciences, Monash University, Australia. Email: Robyn.Benson@med.monash.edu.au Dr Charlotte Brack is a Lecturer at the Faculty of Medicine, Nursing and Health Sciences, Monash University, Australia. Email: Charlotte.Brack@med.monash.edu.au

Please cite as: Samarawickrema, G., Benson, R. \& Brack, C. (2010). Different spaces: Staff development for Web 2.0. Australasian Journal of Educational Technology, 26(1), 4449. http: / / www.ascilite.org.au/ajet/ajet26/samarawickrema.html 